\title{
Interactive comment on "Characterizing
} Uncertainty in the Hydraulic Parameters of Oil Sands Mine Reclamation Covers and its Influence on Water Balance Predictions" by Md. Shahabul Alam et al.

Md. Shahabul Alam et al.

msa181@usask.ca

Received and published: 31 August 2019

In the supplement (ZIP file), we have fully addressed RC2 Dr. Claire Cote's concerns in the highlighted manuscript (HESS Manuscript-2019-154-Highlighted.pdf) and provided a point-by-point response in another file (Response to RC2.pdf). 
Interactive comment on Hydrol. Earth Syst. Sci. Discuss., https://doi.org/10.5194/hess-2019154, 2019.

\section{HESSD}

Interactive

comment 